\title{
HUMAN TOXOCARIASIS: A SEROEPIDEMIOLOGICAL SURVEY IN THE AMAZONIAN CITY OF YURIMAGUAS, PERU
}

\author{
William H. ROLDÁN(1,2), Yuri A. CAVERO(2), Yrma A. ESPINOZA(1,2), Susana JIMÉNEZ(1) \& César A. GUTIÉRREZ(3)
}

\begin{abstract}
SUMMARY
The aim of this study was to determine the seroprevalence of the infection by Toxocara in the general population of the Amazonian city of Yurimaguas, Peru. From March to August 2008, a total of 300 subjects were sampled and tested by means of a Toxocara ELISA-IgG test. A clinical and epidemiological questionnaire was used to assess the symptomatology and risk factors associated with human toxocariasis. The overall rate of seropositivity was $35.66 \%$, with a significant high proportion in children $(\mathrm{p}<0.001)$. The clinical evaluation revealed that $95.33 \%$ of the seropositive group had some type of symptomatology: headache (66.36\%), respiratory compromise (63.55\%), abdominal pain (54.21\%), cutaneous signs (40.19\%) and ocular manifestations (36.45\%), and almost all of them were statistically significant $(\mathrm{p}<0.001)$. Furthermore, $56.07 \%$ of the seropositive subjects presented at least one intestinal pathogen parasite with predominance of helminthes, but without significant association $(\mathrm{p}=0.334)$. The analysis of risk factors showed only that the use of public places and geophagia exhibited a significant association with the seropositivity $(\mathrm{p}<0.001)$. Clinical, serological and epidemiological findings associated to infection with Toxocara were observed in the present study and future studies should be done to assess this serious health problem.
\end{abstract}

KEYWORDS: Toxocariasis; Epidemiology; Survey; ELISA; Peru.

\section{INTRODUCTION}

Human toxocariasis is an accidental parasitic zoonosis caused by larval stages of Toxocara canis and T. cati, the roundworms commonly found in the intestine of dogs and cats, respectively. Adult females of Toxocara can produce up to 200,000 eggs per day, which are excreted into the environment with the feces of their definitive hosts; these eggs become infective within three to five weeks, depending upon certain environment conditions such as the temperature and humidity. When embryonated, Toxocara eggs are accidentally ingested by humans from soil or contaminated food, infective larvae hatch in the small intestine and migrate through the body, but fail to develop to adult stages within this aberrant host ${ }^{5,22,24}$.

The clinical spectrum of human toxocariasis, which varies from asymptomatic infections to severe organ injury, is determined mainly by the parasite load, the sites of larval migration, the inflammatory response and eosinophilia ${ }^{24}$.

Visceral larva migrans (VLM) and ocular larva migrans (OLM) are the two main clinical forms recognized in the literature. VLM or visceral toxocariasis is characterized mainly by fever, hepatomegaly, splenomegaly, respiratory disorders, hypergammaglobulinemia and eosinophilia; OLM is the result after a larval invasion to the eye and their pathological effects including leucocoria, chorioretinitis, optic papillitis, endophthalmitis, can lead to a partial or complete loss of vision. Nevertheless, other syndromes such as covert toxocariasis (CT), neurotoxocariasis (NLM) and other forms have also been described ${ }^{12,22,24,33,34}$.

Because of the difficulty of detecting Toxocara larvae in biopsy tissues, the diagnosis of human toxocariasis is essentially based on immunological assays such as the ELISA test using the excretorysecretory antigens from infective Toxocara larvae (TES) to detect antiToxocara antibodies, which have good sensitivity and specificity ${ }^{14,18,29}$. With the development of this test, several seroepidemiological studies also have been possible $e^{5,22,33}$.

The frequency of human infections by larval stages of Toxocara is high in tropical and developing countries, and is generally associated with low socioeconomic groups ${ }^{15}$, with rates ranging from $1 \%$ in Spain ${ }^{25}$ to $86 \%$ in Santa Lucia $^{36}$; from $3.6 \%$ to $24.7 \%$ in Brazill2, $^{2,4} 47.5 \%$ in Colombia $^{1}$; from $34.9 \%$ to $66.6 \%$ in Venezuela ${ }^{10,21}$, and from $37.9 \%$ to $39 \%$ in Argentina ${ }^{3,27}$. In Peru, a few reports have informed of frequencies from $7.8 \%$ to $44.92 \%$ in rural populations from different places $^{7-9,19,30,31}$. However, seroepidemiological studies about human toxocariasis in Peruvian Amazonian populations have not been reported. 
ROLDÁN, W.H.; CAVERO, Y.A.; ESPINOZA, Y.A.; JIMÉNEZ, S. \& GUTIÉRREZ, C.A. - Human toxocariasis: a seroepidemiological survey in the Amazonian city of Yurimaguas, Peru. Rev. Inst. Med. Trop. São Paulo, 52(1): 37-42, 2010.

The aim of this study was to determine the seroprevalence of infection with Toxocara in Amazonian inhabitants from the district of Yurimaguas, Department of Loreto, Peru, and its association with clinical and epidemiological data.

\section{MATERIAL AND METHODS}

This study was carried out from March to December 2008, in the Amazonian district of Yurimaguas (Latitude $05^{\circ} 55^{\prime} \mathrm{S}$ and Longitude $\left.76^{\circ} 06^{\prime} \mathrm{W}\right)$. The city of Yurimaguas is located at the northwest corner of the Peruvian Amazon at the confluence of the rivers Huallaga and Paranapura, and has a mean altitude of $180 \mathrm{~m}$ above sea level and it is the capital of the province of Alto Amazonas, Department of Loreto, Peru. Yurimaguas has a tropical climate with a mean temperature of 28 ${ }^{\circ} \mathrm{C}$ (between 21.5 and $35^{\circ} \mathrm{C}$ ) and an average relative humidity of $90 \%$.

This district has an approximate population of 61,123 inhabitants. People from rural areas have poor socioeconomic conditions, usually live in neighborhoods and work mainly in trades, agriculture and fishing. From this background, a total of 300 subjects from eight months to 82 years old accepted to participate in this research after their agreement with this study.

An individual questionnaire (including an informed consent) was made and the following clinical data were registered: anamnesis data, clinical signs and symptoms (dry cough, bronchospasms, bronchitis, asthma, hepatosplenomegaly, abdominal pain, leucocoria, strabismus, retinitis, visual loss, headache, convulsions, sleep disturbance and other signs of central nervous system involvement, pruritus, skin rash, chronic weakness, and fatigue); the epidemiological data and risk factors included age, sex, presence of dogs and/or cats at home, the use of public places (i.e. central squares and public parks), history of pica and/or geophagia. This research had the approval of the Ethical Research Committee of the Institute of Tropical Medicine, UNMSM.

For immunological evaluation, blood samples were collected in vacutainer tubes without anticoagulant to obtain serum, which was separated and stored at $-20{ }^{\circ} \mathrm{C}$ until use. For parasitological examination, stool samples also were collected fresh or preserved in $10 \%$ salineformalin solution at room temperature.

Anti-Toxocara IgG antibodies were detected in serum samples by ELISA-IgG test using TES antigens and each serum sample was previously absorbed with total Ascaris suum adult extract in order to avoid the cross- reactions in the immunoassay ${ }^{29}$. All sera were tested at 1:200 dilutions and all stages of the immunoassay were performed at room temperature. The cut-off was set by the mean optical density (OD) of the negative reference serum, plus three times standard deviations. Serum samples with OD above the cut-off value were considered as positive. Additionally, all positive sera were then serially two-fold diluted to determine the relative antibody concentration by titration (the inverse of each dilution).

Coproparasitological examination was realized by direct microscopic observation in fecal smears and by rapid sedimentation technique to detect parasites that can generate cross-reactivity in the serological test ${ }^{20}$.

All data were introduced on an Excel spreadsheet and a statistical analysis was carried out using the program Epi-Info version 6.0. Chisquare test or Fisher's exact test and Odds Ratio (OR) were performed in order to confirm the mean differences between groups. The level of significance selected was $\mathrm{p}<0.05$ and with a significance level of $95 \%$.

\section{RESULTS}

From a total population of 300 subjects (112 male and 188 female), 107 subjects were positive to the ELISA-IgG test, giving an overall frequency of $35.66 \%$. From these 107 subjects with positive serology, $4.66 \%$ had titers of $200,8 \%$ had titers of $400,6.33 \%$ had titers of 800 and $16.66 \%$ had titers of 1600 (Table 1).

The overall frequency of serum anti-Toxocara $\mathrm{IgG}$ antibodies in male subjects was $42.86 \%$ (48/112), whereas the overall frequency in female subjects was $31.38 \%(59 / 188)$. The association between gender and positive serology in the total population showed differences apparently significant in male subjects (Chi-square $=4.03 ; \mathrm{OR}=1.64 ; \mathrm{p}=0.045$ ). On the other hand, an analysis between frequencies of seropositivity and each age group showed a higher significant association in the group of children from eight months to 10 years old (Chi-square $=11.04 ; \mathrm{OR}=$ 2.62; $\mathrm{p}=0.0009)$ (Table 1).

The analysis of the signs/symptoms suggestive of toxocariasis among the studied population showed that $95.33 \%$ of the seropositive group had at least one type of sign or symptom in comparison with a $78.75 \%$ found in the seronegative group. The most frequent clinical findings present in seropositive subjects were headache $(66.36 \%)$, respiratory signs or symptoms $(63.55 \%)$, abdominal pain $(54.21 \%)$, cutaneous signs $(40.19 \%)$, ocular signs or symptoms $(36.45 \%)$ and hepatic compromise (7.47\%), and almost all of them were statistically associated to positive serology (Chi-square $=14.56 ; \mathrm{p}=0.0001 ; \mathrm{OR}=5.5)$ (Table 2).

Table 1

Frequency of anti-Toxocara antibodies according to the age groups in people from the Amazonian city of Yurimaguas, Peru, 2008

\begin{tabular}{|c|c|c|c|c|c|c|c|c|c|c|c|}
\hline \multirow{3}{*}{ Sex } & \multicolumn{10}{|c|}{ Age groups } & \multirow{3}{*}{ Tota } \\
\hline & \multicolumn{2}{|c|}{0 to 10} & \multicolumn{2}{|c|}{11 to 20} & \multicolumn{2}{|c|}{21 to 40} & \multicolumn{2}{|c|}{40 to 60} & \multicolumn{2}{|c|}{61 to 82} & \\
\hline & Pos* & $\mathrm{Neg}$ & Pos & $\mathrm{Neg}$ & Pos & $\mathrm{Neg}$ & Pos & $\mathrm{Neg}$ & Pos & $\mathrm{Neg}$ & \\
\hline Male & 17 & 11 & 6 & 11 & 10 & 20 & 12 & 17 & 3 & 5 & 112 \\
\hline Female & 15 & 16 & 12 & 24 & 19 & 49 & 11 & 34 & 2 & 6 & 188 \\
\hline Total & 32 & 27 & 18 & 35 & 29 & 69 & 23 & 51 & 5 & 11 & 300 \\
\hline
\end{tabular}

* Pos $=$ seropositive Neg $=$ seronegative 
ROLDÁN, W.H.; CAVERO, Y.A.; ESPINOZA, Y.A.; JIMÉNEZ, S. \& GUTIÉRREZ, C.A. - Human toxocariasis: a seroepidemiological survey in the Amazonian city of Yurimaguas, Peru. Rev. Inst. Med. Trop. São Paulo, 52(1): 37-42, 2010.

Table 2

Distribution of signs and symptoms as related to serology for toxocariasis in people from Yurimaguas city, Peru, 2008

\begin{tabular}{|c|c|c|c|c|c|c|c|c|}
\hline \multirow[b]{2}{*}{ Clinical findings* } & \multicolumn{4}{|c|}{ Anti-Toxocara IgG antibodies } & \multicolumn{2}{|c|}{ Bivariate analysis } & \multicolumn{2}{|c|}{ Multivariate analysis ${ }^{* * *}$} \\
\hline & $\begin{array}{c}\text { Seropositive } \\
(\mathrm{n}=107)\end{array}$ & $\%$ & $\begin{array}{l}\text { Seronegative } \\
\quad(\mathrm{n}=193)\end{array}$ & $\%$ & $\mathrm{p}$ value** & OR $(95 \% \mathrm{CI})$ & $\mathrm{p}$ value & OR $(95 \% \mathrm{CI})$ \\
\hline Symptomatic (any) & 102 & 95.33 & 152 & 14.56 & $<0.001$ & $5.50(2.10-14.40)$ & & \\
\hline $\begin{array}{l}\text { Pulmonary } \\
\text { manifestations }\end{array}$ & 68 & 63.55 & 46 & 23.83 & $<0.001$ & $5.57(3.33-9.32)$ & 0.008 & $2.921(1.33-6.40)$ \\
\hline $\begin{array}{l}\text { Hepatic } \\
\text { manifestations }\end{array}$ & 8 & 7.47 & 18 & 9.33 & $<0.001$ & $0.79(0.33-1.87)$ & & \\
\hline Ocular manifestations & 39 & 36.45 & 57 & 29.53 & 0.5854 & $1.37(0.83-2.26)$ & & \\
\hline Headache & 71 & 66.36 & 11 & 5.69 & $<0.001$ & $32.63(15.74-67.63)$ & $<0.001$ & $\begin{array}{c}14.502(4.21- \\
49.92)\end{array}$ \\
\hline Abdominal pain & 58 & 54.21 & 92 & 47.67 & 0.278 & $1.30(0.81-2.09)$ & & \\
\hline $\begin{array}{l}\text { Weakness and/or } \\
\text { fatigue }\end{array}$ & 30 & 28.03 & 11 & 5.69 & $<0.001$ & $6.45(3.07-13.52)$ & $<0.001$ & $\begin{array}{c}35.52(14.38- \\
87.75)\end{array}$ \\
\hline
\end{tabular}

*Some subjects had more than one sign/symptom; **p $<0.05$ = significant value (Chi-square); *** variables in the model: sex, age, pulmonary and hepatic manifestations, headache, and weakness and/or fatigue.

The parasitological analysis was carried out only in 223 subjects because some people would not accept collecting their stool samples. Even so, the study revealed that $70.40 \%$ (157/223) of the population were infected. The protozoan parasites found were as follows: Blastocystis hominis in $22.43 \%$, Giardia lamblia in $5.61 \%$, Entamoeba histolytica/E. dispar in $0.93 \%$, and Cyclospora cayetanensis $0.93 \%$. From subjects with positive serology, $56.07 \%(60 / 107)$ had at least one intestinal parasite. The most prevalent intestinal nematodes found in the study population were: Ascaris lumbricoides (12.15\%), Hymenolepis nana (5.61\%), and Trichuris trichiura $(1.87 \%)$. However, their association with a positive serology revealed not to be significant (Chi-square $=0.93 ; \mathrm{p}=0.334$; $\mathrm{OR}=1.26$ ).

The analysis of risk factors evidenced that the presence of dogs and/or cats within the houses showed no significant association with seropositivity (Chi-square $=2.6 ; \mathrm{p}=0.107 ; \mathrm{OR}=1.64$ ). Nevertheless, the use of parks or other public places showed a significant association with the seropositivity as well as a previous history of pica or geophagia $(\mathrm{p}<0.001)$ (Table 3).

\section{DISCUSSION}

Toxocariasis is a helminthic zoonosis with a worldwide distribution and, until now, it continues to be an almost unknown disease among the health professionals or general population.

In the present study, we have observed an overall anti-Toxocara antibodies frequency of $35.66 \%$ in the general population from the Amazonian city of Yurimaguas, with a higher significant proportion in children from eight months to 10 years old, suggesting that they were the main group in contact with the parasite and the main group at risk of toxocariasis, as reported by other authors ${ }^{22,24,33}$. This value is among the values of frequency previously found in other places from our country ${ }^{7-9,30,31}$ and relatively similar with other studies from other Latin American countries $2,3,21,27$.

From the seropositive subjects, 16.66\% (50/107) had titers of 1600 for anti-Toxocara IgG antibodies, mainly in children from one to 10 years old, suggesting a strong immunological response due to the larval infection by Toxocara.

Table 3

Distribution of risk factors as related to serology for toxocariasis in people from Yurimaguas city, Peru, 2008

\begin{tabular}{|c|c|c|c|c|c|c|c|c|}
\hline \multirow[b]{2}{*}{ Risk factors } & \multicolumn{4}{|c|}{ Anti-Toxocara $\operatorname{IgG}$ antibodies } & \multicolumn{2}{|c|}{ Bivariate analysis } & \multicolumn{2}{|c|}{ Multivariate analysis** } \\
\hline & $\begin{array}{l}\text { Seropositive } \\
(\mathrm{n}=107)\end{array}$ & $\%$ & $\begin{array}{c}\text { Seronegative } \\
\quad(n=193)\end{array}$ & $\%$ & p value* & OR $(95 \% \mathrm{CI})$ & $\mathrm{p}$ value & OR $(95 \% \mathrm{CI})$ \\
\hline $\begin{array}{l}\text { Ownership of dogs } \\
\text { and/or cats at home }\end{array}$ & 89 & 83.18 & 145 & 75.13 & 0.107 & $1.64(0.90-2.99)$ & & \\
\hline $\begin{array}{l}\text { Use of parks and/or } \\
\text { public places }\end{array}$ & 93 & 86.92 & 127 & 65.80 & $<0.001$ & $3.45(1.83-6.52)$ & $<0.001$ & $0.14(0.021-0.394)$ \\
\hline $\begin{array}{l}\text { History of pica or } \\
\text { geophagia }\end{array}$ & 28 & 26.17 & 12 & 6.22 & $<0.001$ & $5.35(2.59-11.05)$ & $<0.001$ & $0.223(0.105-0.477)$ \\
\hline
\end{tabular}

$* \mathrm{p}<0.05=$ significant value; $* *$ variables in the model: sex, age, use of parks and/or public places, and history of pica or geophagia. 
ROLDÁN, W.H.; CAVERO, Y.A.; ESPINOZA, Y.A.; JIMÉNEZ, S. \& GUTIÉRREZ, C.A. - Human toxocariasis: a seroepidemiological survey in the Amazonian city of Yurimaguas, Peru. Rev. Inst. Med. Trop. São Paulo, 52(1): 37-42, 2010.

In agreement with other authors, we have also found statistically significant differences between gender and positive serology indicating that male subjects are more associated at risk of toxocariasis than female subjects, probably because of their close contact with soil, as is the case

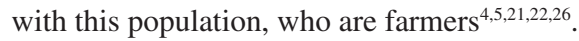

The clinical assess of the symptomatology suggestive of toxocariasis indicates to us a highly significant association with positive serology and more evidence of toxocariasis cases in this population $(\mathrm{p}<0.001)$. Clinical findings such as respiratory compromise (asthmatic syndrome, bronchial spasm, bronchitis or dry cough) were highly significant $(\mathrm{p}<$ $0.001)$ as well as headache $(\mathrm{p}<0.001)$ and weakness or fatigue $(\mathrm{p}<$ 0.001). On the other hand, clinical findings such as hepatic compromise and abdominal pain, ocular and cutaneous manifestations were also frequent, but less associated to the positive serology.

It is interesting to mention that the clinical findings associated to the positive serology were more frequently found in children between one and 10 years old (data not shown). On this point, many authors are in agreement that toxocariasis cases are more frequently associated and diagnosed in pediatric patients. However, VLM cases are less frequent in comparison with other forms of toxocariasis, such as incomplete VLM or covert toxocariasis ${ }^{22,24,34}$.

Taking into consideration that the clinical manifestations found in these children are associated with middle or high titers of anti-Toxocara antibodies, we think that they could be presenting some clinical picture compatible with covert toxocariasis. Unfortunately, we could not take additional blood samples for hematological examination in order to assess their levels of leukocytes and eosinophils. Therefore, this is a limitation of our study.

Other clinical findings frequently associated to toxocariasis are hepatic compromise or abdominal pain. Nevertheless, the result of the multivariate analysis reveals a poor association with the positive serology, suggesting other causes for their presence in the studied population. It is possible that intestinal parasites (found in a high frequency in this population) could be the main cause for the presence of these symptoms.

On the other hand, visual loss and/or ocular pain, which are associated to ocular toxocariasis, have a poor association with the positive serology, suggesting other causes for their presence in the studied population. Similarly, cutaneous signs also were present in seropositive subjects, but they were insufficient to be associated to the serology, contradicting the findings of other authors ${ }^{14,17}$.

Ownership of pets such as dogs or cats and their presence at home is frequently associated with toxocariasis, as mentioned by many authors ${ }^{5,22,24,28,34-37}$. However, this fact was not associated with the seropositivity in the studied population $(\mathrm{p}=0.107)$. On the other hand, the use of public parks or places by those people were highly associated with the positive serology $(\mathrm{p}<0.001)$, suggesting that Toxocara eggs might be present in those places and to be a main source for infection in this population. Canine feces are frequent in public places and playgrounds in other countries, as reported by other authors around the world ${ }^{1,5,15,22,24,33}$. Although limited studies about soil contamination with Toxocara eggs in Peru have revealed a frequency ranging from $30 \%$ to $80 \%{ }^{19}$. It is possible that the infection occurring in this population might have also happened by an accidental ingestion of infective Toxocara eggs from the soil of those public places.

Geophagia (eating soil) is a specific type of pica that increases the risk of toxocariasis, especially in children living in homes with infected puppies and kittens or as atypical behavior of playing on the soil ${ }^{5,22,33}$. In this study, we have found that geophagia was significantly associated to positive serology $(\mathrm{p}<0.001)$. Moreover, association of geophagia with toxocariasis were reported in several studies around the world, since human toxocariasis has been described as a soil transmitted zoonosis $2,5,17,22,24$.

A high frequency of intestinal parasites might occasionally be found together with Toxocara infection and the statistical association between them could be close related. Nevertheless, this kind of association was not significant with regards to the positive serology $(p=0.334)$. However, their presence shows that this population has poor hygiene habits and sanitary behavior.

We also note that the presence of mixed infections between Toxocara and other helminthes might increase the frequency of seropositivity using conventional serological tests, but with the previous serum absorption with Ascaris suum antigens, we might diminish or avoid the possible cross-reactions, as recommended by other authors ${ }^{6,23}$.

The high rate for toxocariasis frequency found in this study could be the result of several factors, but doubtless the most important is the social characteristics of the rural neighborhoods from Yurimaguas city, a tropical town with many areas of unpaved streets, deficient in the daily cleaning of them and dogs living on the streets. On this point, many authors report that similar conditions found in people living in tropical places from

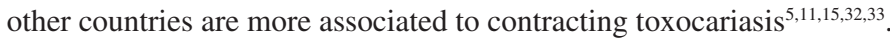

Clinical, serological and epidemiological findings associated to Toxocara infection were observed in the present study. Future studies about soil contamination with Toxocara eggs should be performed to better assess and control the magnitude of this serious health problem, and community education programs should be developed to inform people about zoonotic parasitosis and promote the social concept of responsible pet ownership.

\section{RESUMO}

\section{Toxocaríase humana: inquérito soroepidemiológico na cidade amazônica de Yurimaguas, Peru}

O objetivo do presente estudo foi estimar a soroprevalência da infecção por Toxocara em população geral da cidade de Yurimaguas, Peru. Entre os meses de Março e Agosto de 2008, foi estudado um total de 300 pessoas por exame imunológico mediante Toxocara ELISA-IgG teste. Uma ficha clínico-epidemiológica foi utilizada para avaliar a sintomatologia e os fatores de risco associados à toxocaríase. A frequiência geral de anticorpos na população foi de $35,66 \%$ com proporção significativamente maior de positividade em meninos de um a 10 anos (p < 0.001). A avaliação clínica revelou que $95.33 \%$ do grupo de soropositivos apresentava algum tipo de sintomatologia associada à toxocaríase: $66,36 \%$ cefaléia, $63,55 \%$ sintomas respiratórios, $54,21 \%$ dor abdominal, 40,19\% sinais cutâneos e 36,45\% manifestações oculares e quase todos estes sinais foram estatisticamente associados ao resultado 
ROLDÁN, W.H.; CAVERO, Y.A.; ESPINOZA, Y.A.; JIMÉNEZ, S. \& GUTIÉRREZ, C.A. - Human toxocariasis: a seroepidemiological survey in the Amazonian city of Yurimaguas, Peru. Rev. Inst. Med. Trop. São Paulo, 52(1): 37-42, 2010.

da sorologia ( $\mathrm{p}<0.001)$. Além disso, $56,07 \%$ das pessoas com sorologia positiva tinham pelo menos algum parasito intestinal patogênico e com predominância de helmintos, mas sem nenhuma associação significativa $(p=0.334)$. A análise dos fatores de risco mostrou que o uso de lugares públicos e história de geofagia tiveram significativa associação com a sorologia positiva $(\mathrm{p}<0,001)$. Conclui-se que existem evidências clínicas, sorológicas e epidemiológicas de infecção por Toxocara na população estudada e futuros estudos são necessários para avaliar este sério problema de saúde pública.

\section{ACKNOWLEDGEMENTS}

To Red de Salud Alto Amazonas (MINSA) and Centro Médico Yurimaguas (ESSALUD) for their invaluable help with the coordination of the field activities; to Wagner Rosas and Dino Huancollo for their technical assistance, and the population from Yurimaguas for their kindly cooperation with the development of this study. This work received financial support from the UNMSM - CSI Research Project $\mathrm{N}^{\circ} 080101221$.

\section{REFERENCES}

1. Agudelo C, Villareal E, Cáceres E, López, C, Eljach J, Ramírez N, et al. Human and dogs Toxocara canis infection in a poor neighborhood in Bogotá. Mem Inst Oswaldo Cruz. 1990;85:75-8.

2. Alderete JMS, Jacob CMA, Pastorino AC, Elefant GR, Castro AP, Fomin AB, et al. Prevalence of Toxocara infection in schoolchildren from the Butantã region, São Paulo, Brazil. Mem. Inst. Oswaldo Cruz. 2003;98:593-7.

3. Alonso JM, Bojanich MVI, Chamorro M, Gorodner JO. Toxocara frequency in children from a subtropical city in Argentina. Rev Inst Med Trop Sao Paulo. 2000;42:235-7.

4. Chieffi PP, Ueda M, Camargo ED, De Souza AM, Guedes ML, Gerbi LJ et al. Visceral larva migrans: a seroepidemiological survey in five municipalities of São Paulo state, Brazil. Rev Inst Med Trop Sao Paulo. 1990;32:204-10.

5. Despommier D. Toxocariasis: clinical aspects, epidemiology, medical ecology, and molecular aspects. Clin Microbiol Rev. 2003;16:265-72.

6. Elefant GR, Shimizu SH, Sanchez MC, Jacob CM, Ferreira AW. A serological follow-up of toxocariasis patients after chemotherapy based on the detection of $\operatorname{IgG}, \operatorname{IgA}$, and $\operatorname{IgE}$ antibodies by enzyme-linked immunosorbent assay. J Clin Lab Anal. 2006;20:164-72.

7. Espinoza Y, Huapaya P, Sevilla C, Huiza A. Toxocariosis humana: seroprevalencia en la población de Lima mediante la técnica de ELISA. An Fac Med (Peru). 2003;64:22832 .

8. Espinoza Y, Huapaya P, Ayllón C, Sevilla C, Huiza A, Jiménez S. Toxocariosis humana en pacientes con lesión ocular. An Fac Med (Peru). 2003;64:247-51.

9. Espinoza YA, Huapaya PH, Roldán WH, Jiménez S, Arce Z, Lopez E. Clinical and serological evidence of Toxocara infection in school children from Morrope district, Lambayeque, Peru. Rev Inst Med Trop Sao Paulo. 2008;50:101-5.

10. Felix-Pífano CF, Orihuela AR, Delgado O, Cortez R, Abdul Hadi S, Dale de Ortíz M. La toxocariasis humana en Venezuela, especialmente en el valle de Caracas. Gac Méd Caracas. 1989;97:31-41.

11. Ferreira MU, Rubinsky-Elefant G, De Castro TG, Hoffmann EH, Da Silva-Nunes M, Cardoso MA, et al. Bottle feeding and exposure to Toxocara as risk factors for wheezing illness among under-five Amazonian children: a population-based crosssectional study. J Trop Pediatr. 2007;53:119-24.

12. Finsterer J, Auer H. Neurotoxocarosis. Rev Inst Med Trop Sao Paulo. 2007;49:279-87.
13. Gavignet B, Piarroux R, Aubin F, Millon L, Humbert P. Cutaneous manifestations of human toxocariasis. J Am Acad Dermatol. 2008;59:1031-42.

14. Glickman L, Schantz P, Dombroske R, Cypess R. Evaluation of serodiagnostic test for visceral larva migrans. Am J Trop Med Hyg. 1978;27:492-8.

15. Hotez PJ, Wilkins PP. Toxocariasis: America's most common neglected infection of poverty and a helminthiasis of global importance? PLoS Negl Trop Dis. 2009;3:e400.

16. Humbert P, Niezborala M, Salembier R, Aubin F, Piarroux R, Buchet S, et al. Skin manifestations associated with toxocariasis: a case-control study. Dermatology. 2000;201:230-4.

17. Iddawela DR, Kumarasiri PV, de Wijesundera MS. A seroepidemiological study of toxocariasis and risk factors for infection in children in Sri Lanka. Southeast Asian J Trop Med Public Health. 2003;34:7-15.

18. Jacquier P, Gottstein B, Stinlegin Y, Eckert J. Immunodiagnosis of toxocariasis in humans: evaluation of a new enzyme-linked immunosorbent assay kit. J Clin Microbiol. $1991 ; 29: 1831-5$

19. Lescano SAZ, Chieffi P, Peres B, De Mello EO, Velarde CN, Salinas AA, et al. Soil contamination and human infection by Toxocara sp. in the urban area of Lima, Peru. Mem Inst Oswaldo Cruz. 1998;93:733-4.

20. Lumbreras H, Cantella R, Burgos R. Acerca de un procedimiento de sedimentación rápida para investigar huevos de Fasciola hepatica en las heces. Su evaluación y uso en el campo. Rev Med Peru. 1964;31:167-74.

21. Lynch NR, Eddy K, Hodgen AN, Lopez RI, Turner KJ Seroprevalence of Toxocara canis infection in tropical Venezuela. Trans R Soc Trop Med Hyg. 1988;82:275-81.

22. Magnaval JF, Glickman LT, Dorchies P, Morassin B. Highlights of human toxocariasis. Korean J Parasitol. 2001;39:1-11.

23. Nunes CM, Tundisi RN, Garcia JF, Heinemann MB, Ogassawara S, Richtzenhain LJ. Cross-reactions between Toxocara canis and Ascaris suum in the diagnosis of visceral larva migrans by Western blotting technique. Rev Inst Med Trop Sao Paulo. 1997:39:253-6.

24. Pawlowski Z. Toxocariasis in humans: clinical expression and treatment dilemma. J Helminthol. 2001;75:299-305.

25. Portús M, Riera C, Prats G. A serological survey of toxocariasis in patients and healthy donors in Barcelona (Spain). Eur J Epidemiol 1989;5:224-7.

26. Queiroz ML, Simonsen M, Paschoalotti MA, Chieffi PP. Frequency of soil contamination by Toxocara canis eggs in the south region of São Paulo municipality (SP, Brazil) in a 18 month period. Rev Inst Med Trop Sao Paulo. 2006;48:317-19.

27. Radman NE, Archelli SM, Fonrouge RD, Guardis M, Linzitto OR. Human toxocarosis Its seroprevalence in the city of La Plata. Mem Inst Oswaldo Cruz. 2000;95:281-5

28. Roddie G, Stafford P, Holland C, Wolfe A. Contamination of dog hair with eggs of Toxocara canis. Vet Parasitol. 2008;152:85-93.

29. Roldán W, Cornejo W, Espinoza Y. Evaluation of the dot-ELISA in comparison with standard ELISA for the immunodiagnosis of human toxocariasis. Mem Inst Oswaldo Cruz. 2006;101:71-4.

30. Roldán WH, Espinoza YA, Atúncar A, Ortega E, Martinez A, Saravia M. Frequency of eosinophilia and risk factors and their association with Toxocara infection in schoolchildren during a health survey in the north of Lima, Peru. Rev Inst Med Trop. Sao Paulo. 2008;50:273-8.

31. Roldán WH, Espinoza YA, Huapaya PE, Huiza AF, Sevilla CR, Jiménez S. Frequency of human toxocariasis in a rural population from Cajamarca, Peru determined by DOT-ELISA test. Rev Inst Med Trop Sao Paulo. 2009;51:67-71. 
ROLDÁN, W.H.; CAVERO, Y.A.; ESPINOZA, Y.A.; JIMÉNEZ, S. \& GUTIÉRREZ, C.A. - Human toxocariasis: a seroepidemiological survey in the Amazonian city of Yurimaguas, Peru. Rev. Inst. Med. Trop. São Paulo, 52(1): 37-42, 2010.

32. Rubinsky-Elefant G, Da Silva-Nunes M, Malafronte RS, Muniz PT, Ferreira MU. Human toxocariasis in rural Brazilian Amazonia: seroprevalence, risk factors, and spatial distribution. Am J Trop Med Hyg. 2008;79:93-8.

33. Smith H, Holland C, Taylor M, Magnaval JF, Schantz P, Maizels R. How common is human toxocariasis? Towards standardizing our knowledge. Trends Parasitol. 2009;25:182-8.

34. Taylor MR, Keane CT, O'Connor P, Girdwood RW, Smith H. Clinical features of covert toxocariasis. Scand J Infect Dis. 1987;19:693-6.

35. Teixeira CR, Chieffi PP, Lescano SA, De Melo Silva EO, Fux B, Cury MC. Frequency and risk factors for toxocariasis in children from a pediatric outpatient center in southeastern Brazil. Rev Inst Med Trop Sao Paulo. 2006;48:251-5.
36. Thompson DE, Bundy DAP, Cooper ES, Schantz PM. Epidemiological characteristics of Toxocara canis zoonotic infection of children in a Caribbean community. Bull World Health Organ. 1986;64:283-90.

37. Wolfe A, Wright IP. Human toxocariasis and direct contact with dogs. Vet Rec 2003;152:419-22.

Received: 9 October 2009

Accepted: 30 November 2009 